\title{
Using Zoom to Support English Learning during Covid-19 Pandemic: Strengths and Challenges
}

\section{Nafisatul Mu'awanah', Sumardi2, Suparno ${ }^{3}$}

1,2,3 Sebelas Maret University, Surakarta, Indonesia

\section{A R T I C L E I N F O}

Article history:

Received March 10, 2021

Revised March 12, 2021

Accepted April 30, 2021

Available online May 25, 2021

Kata Kunci:

Pembelajaran Bahasa Inggris, Pembelajaran Online, Kekuatan Dan Tantangan, Zoom

Keywords:

English Learning, Online Learning, Strength And Challenge, Zoom

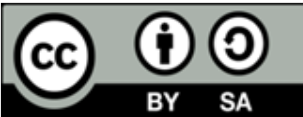

This is an open access article under the CC BY-SA license.

Copyright (C) 2021 by Author. Published by Universitas Pendidikan Ganesha.

\begin{abstract}
A B S T RA K
Pandemi COVID-19 menyebabkan institusi pendidikan menerapkan kebijakan pembelajaran jarak jauh. Zoom adalah salah satu platform populer untuk mengoptimalkan pembelajaran online melalui konferensi video. Penelitian ini bertujuan untuk mengeksplorasi kekuatan dan tantangan penggunaan Zoom untuk mendukung pembelajaran bahasa Inggris jarak jauh. Pendekatan kualitatif dengan desain inkuiri naratif digunakan dan siswa dari sekolah menengah pertama secara sukarela berpartisipasi. Wawancara digunakan sebagai metode pengumpulan data, dan data divalidasi dengan triangulasi dan dianalisis dengan mengikuti analisis model interaktif. Studi ini mengungkapkan bahwa belajar bahasa Inggris melalui Zoom membantu siswa untuk berlatih bahasa Inggris, membuat proses belajar-mengajar lebih efektif, dan memfasilitasi interaksi dan komunikasi guru-siswa. Apalagi, fitur-fitur di Zoom mendukung pembelajaran bahasa Inggris jarak jauh. Semua manfaat tersebut membawa dampak yang baik pada hasil belajar bahasa Inggris siswa. Sementara itu, Zoom juga menantang bagi siswa dengan koneksi internet yang lambat dan gadget yang tidak mendukung. Kegiatan tersebut juga mengeluarkan biaya tambahan untuk tagihan internet dan membutuhkan lingkungan belajar yang kondusif. Disarankan kepada pemerintah perlu menyediakan fasilitas yang lebih baik untuk mendukung pembelajaran online, seperti menyediakan akses internet yang baik.
\end{abstract}

A B S T R A C T

COVID-19 pandemic caused educational institutions apply remote distance learning policy. Zoom is one of popular platforms to optimize online learning through video conference. This study aimed to explore strengths and challenges of using Zoom to support distance English learning. A qualitative approach with narrative inquiry design was employed and students from a junior high school voluntarily participated. Interview was deployed as data collection methods, and the data were validated by triangulation and analyzed by following the interactive model analysis. The study reveals that learning English via Zoom help students to practice English, make teaching-learning process more effective, and facilitate the teacher-student interaction and communication. Moreover, features on Zoom support distance English learning. Those all benefits bring good impact on students' English learning output. Meanwhile, Zoom is also challenging for students with slow internet connection and unsupported gadget. The activity also spends extra cost for internet bill and need conducive learning environment. It is suggested that government needs to provide better facilities to support online learning, such as providing good internet acces.

\section{INTRODUCTION}

The COVID-19 pandemic caused some schools and universities applyremote distance learning policy (Mishra et al., 2020; Oyedotun, 2020; Patricia, 2020; Purwanto et al., 2020; Sahu, 2020), and the use of online learning platforms is encouraged by the current wave of school closures (Reimers, Fernando \& Andreas, 2020). The outbreak has given us the chance to pave the way for digital learning (Dhawan, 2020). Online learning seems to be a solution to situations and circumstances that cause traditional learning impossible (Wargadinata, et al., 2020). The solutions bring teachers into multiple online platforms, which is a paradigm change. Despite the difficulties faced by both teachers and students, online learning has become a challenge for this ongoing global pandemic (Pokhrel, Sumitra \& Chhetri, 2021). 
Beside the factor of covid-19 pandemic, the emergency of the use of online platforms in teaching learning process is also initiated based on the fact that studentsnowadays are digital natives. They are getting accustomed to use gadgets and surrounded by online platforms (Suadi, 2021).

In English class, some online applications are popular to use such as Whatsapp, Google Classroom, Google Form, Edmodo, Moodle, etc. Each application has its own strength and weaknesses. As the distance learning is implemented, teachers sometimes need to check students' presence in class and discuss many things directly by video conference. In addition, video conference is regarded as the best approximates the traditional classroom approach to teaching (Lowenthal \& West, 2020). In other words, the use of video conference in learning can be the most effective way to check the students' academic and emotional wellbeing (Lowenthal \& West, 2020). In this online environment, peoplecommonly use a web-cam and a microphone to chat in real time, creating interactions similar to those found in the traditional classroom setting (Rahayu, 2020). Variousvideo conference applications are available such as Skype, Zoom, Webex, Google Meet, etc. Zoom is the most likely popular video conferencing platform used during this pandemic period to support discussions or meeting through video conference. Zoom is considered beneficial in the teaching learning process since disconnection problems never happen in Zoom. Besides, the audio in online video sharing in the Zoom can be heard clearly by all participants. In addition, Zoom provides Breakout Rooms which is not available in other platforms. This feature allows teachers to divide students into some smaller groups. The teachers can visit each group to check how the presentation and the conversation among the participants are going on. After the time is set, the participants will automatically be led back to the "main room" once the session finishes. Another helpful feature is co-annotating and remote control. By using remote control feature, the teachers are able to give the mouse access to the participants. This is advantegous when the participants are given a change to do presentation so they can use the mouse access to click the point explained on screen. Theco-annotate feature provides the access to every participant to use arrow, line, pen, etc. This feature, especially the arrow, is useful for participants when the instructor asks them to point out pictures of specific words or locations in screen (Dharma, Asmarani, \& Dewi., 2017).

This research is considered to be urgent in this panemic since all education levels including junior high school all at once have to move to online learning while everything has not been prepared well. So, this research is expected to be a contribution to the education in Indonesia to figure out strength and weaknesses of using Zoom video conference in distance English learning. The findings and discussion of this research can be a consideration for the education institution to use the platform or not especially for junior high school students. A few studies have looked into the subject of using Zoom for English learning. The study showed that EFL University students considered Zoom as a positive platform for learning. Despite the fact that the slow internet connection was the main issue during the online meeting, zoom video conferencing was rated effective and efficient in terms of time, place, and cost. Moreover, zoom platform helps students improve language skills and reduce shyness in virtual class interaction. According to the findings, the Zoom platform is an excellent communication method. Students may use the chat box to communicate with another student, their English teacher, or the whole group. They have access to everyone's camera and can listen in on everyone's conversations. English teachers can use the breakout rooms to group lessons. It is used for the breakout rooms to group learners in pairs, threes or in whatever size group they want.

In the previous researches, the participants are all adults: university students. There was limited research that studied the similar topic with junior high school students in English class as participants. The various levels of participants with different background and context of English learning perhaps reveal more complex findings and impacts related to the topic. Therefore, in the further studies, the writer is going to conduct a research with junior high school students as the participants in which English is a foreign language in Indonesia. In addition, the writer would like to figure out the capability of junior high school students $\left(13^{\text {th }}-14^{\text {th }}\right.$ years old) in using ICT to join distance English learning through Zoom video conference by questioning their perception on strengths and challenges in using Zoom for learning English. Contribution to the literature; 1) This study explored the potential online platform, Zoom, to support distance learning during Covid-19 pandemic on English learning epecially for junior high school students in Indonesia. 2) This study highlighted the strength and challenges of using Zoom for learning so that in the future educational institution as well as Indonesian government prepare ways to optimize the stregth and overcome the problems. 3) This study proposed suggestions for stepping up preparedness by bringing in pedagogical strategies to ensuring that students can learn English at home with fun and reduce their obstacles. This study aims to figure out students' perception on the strength and challenges of using Zoom video conference to support distance English language teaching. It means, the researcher will explore students' perception about the use of Zoom in teaching English in pandemic era, and will reveal 
whether or not it supports distance English language teaching. The topic is important since pandemic brings all level of education to online learning in which students must be familiar with.

\section{METHOD}

This research is qualitative with narrative inquiry approach. Claimed that narrative inquiry tells the narrative experience including educational experience to understand the phenomena from participants' perspectives Clandinin\& Connelly (2000) as cited in (Clandinin, 2006). This research aims to explore the students' perception on strength and weaknesses of using Zoom to support distance English learning during COVID-19 pandemic. The respondents in this research were 256 students of secondary school. Among those students, 21 students were selected using purposive sampling technique where respondents are deliberately chosen to be investigated (Creswell, 2012). They were the students who voluntarily participated in Zoom English class. The instrument used in this study was interview. The participants were interviewed one by one through Whats App voice call which was recorded using voice recorder in smart phone and then transcribed and analyzed qualitatively. The interview contained questions about the students' opinion on the use of Zoom video conference in English class. The instrument grid is presented in the Table 1.

Table 1. The Instrument Grid of Interview

\begin{tabular}{|c|c|c|}
\hline Indicators & Sub-indicators & $\begin{array}{c}\text { Number of } \\
\text { Question Items }\end{array}$ \\
\hline \multirow{2}{*}{ Affective } & $\begin{array}{l}\text { Students' impression or feeling in interpreting the use of Zoom } \\
\text { video conference in supporting distance ELT }\end{array}$ & 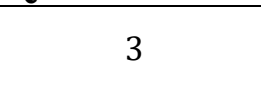 \\
\hline & $\begin{array}{l}\text { Students' interest and motivation in joining distance ELT via } \\
\text { Zoom video conference }\end{array}$ & 2 \\
\hline \multirow{4}{*}{ Cognitive } & $\begin{array}{l}\text { Students' attitude on the use of Zoom video conference in } \\
\text { supporting distance ELT related to their English proficiency }\end{array}$ & 2 \\
\hline & $\begin{array}{l}\text { Students' attitude on their engagement in distance ELT via } \\
\text { Zoom video conference }\end{array}$ & 2 \\
\hline & $\begin{array}{l}\text { Students' attitude on their preference or ignorance on distance } \\
\text { ELT via Zoom video conference }\end{array}$ & 4 \\
\hline & $\begin{array}{l}\text { Students' opinion about the features of Zoom platform in } \\
\text { supporting distance ELT }\end{array}$ & 2 \\
\hline conative & $\begin{array}{l}\text { Students' attitude and tendency to behave about the use of } \\
\text { Zoom video conference in supporting distance ELT }\end{array}$ & 2 \\
\hline
\end{tabular}

The data collected were analyzed by following the interactive model of data analysis with four fundamental stages, i.e. data collection, data condensation, data display, and drawing and verifying conclusion (Miles, Huberman, \& Saldaña, 2014). The flow of research used is presented in Figure 1.

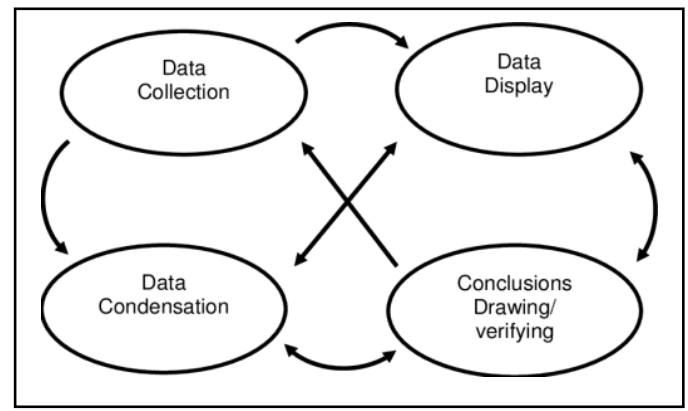

Figure 1. Interactive Model (Miles, Huberman \&Saldaña, 2014)

The process of data collection was conducted as explained in the previous section, and followed by data triangulation assigned to pursue the clarity of research data. Data condensation was the process of selecting, focusing, simplifying, abstracting, and/or transforming the data that appear in the full body of written-up field notes, interview transcripts, and documents. It was carried out by creating codes and categories to guide the data to research questions. Data was subsequently displayed narratively. The data analysis was eventually ended by drawing and verifying the conclusions. 


\section{RESULT AND DISCUSSION Result}

The findings of the present study include the results of students' perception of strengths and challenges in using zoom to support English learning during covid-19 pandemic. The transcript of interview provided data of each participants' opinion. It is worthy of notice because the interviews were in Indonesian, so all the direct quotations reported in this section were translated into English. First, In the previous online classroom setting, students communicated with teacher via chatting in Whats App group and Google Classroom. They stated that they felt lack of confidence to ask teacher when they did not understand the material since sometimes the teacher did not directly answer the question, or even ignored. Using Zoom video conference, teacher directly and orally responded to students' questions. In addition, students also glad to meet teacher and friends virtually during the online learning as students stated, "Learning English via Zoom is helpful because students and teacher can have direct question and answer. Teacher was usually too long to reply the chat." The statement shows that the student needed direct face-to-face communication as they usually did in traditional classroom. This is important since students sometimes cannot understand teacher's explanation, and need more clarification until they truly understand about the material. Secord, using chatting application such as Whats App or Google Classroom, teacher is mostly too long to reply the chat. This happens because teachers have much jobs to do after class or when the class runs, or their private is distracted by students' chats that mostly out of lesson time. Direct communication is one of students' basic needs during learning process, as students said, "The explanation is more detail. I and friends also get similar explanation and understanding from teacher, not only guessing" The written explanation also creates various perceptions that students are doubtful whether their understanding to the material is right or wrong, and they are reluctant to confirm many times in chat. In other words, oral explanation through Zoom video conference provides more detailed explanation as it is face to face in classroom.

Third, in addition, video conference meeting is truly needed since students' engagement in distance learning activity is hard to be controlled. The routine activity is teacher delivers materials and students try to understand it well by themselves. Then, they work on assignments and submit them. This fact makes teacher is doubtful whether their students engage in learning activity or not. Using Zoom, students have more positive participation on learning process as students said, "We become more active, and ask something if I don't understand the material. Sometimes other friends also ask something that reminds me to the topic." Different from the usual learning activity where students are only read the material and fill in the attendant list on Whatsapp Group, Google Classroom or Google Form, Zoom makes students are actively joined the learning activity which can be easily control by teacher as a student said, "Zoom makes me focus on the lesson. Usually, I only read the material on group, do tasks and fill in the presence list." Fourth, it has been almost a year for students to have distance learning. In fact, they feel bored with the activity and the platform used such as Whats App, Google Classroom, Google Form etc. which they everyday face the tasks, and try to understand material by themselves without any clear clarification from teacher. In addition, learning at home alone with gadgets make students less motivated and hard to learn based on schedule as a student stated, "Learning alone at home makes me feel sleepy. I tend to be lazy and postpone everything. I feel bored reading written greeting and materials." Emotional connection between teacher and students brings good impact on students' engagement and active participation in classroom. This can make them really focus on learning and automatically understand the English material better since. However, New learning platform means new experience in using technology for learning. 75\% of participants never use Zoom before. They started with install, learn how to use it, try the features in it, until they can use it for participating distance English lesson as a student stated, "I feel that I experience new technology for learning especially Zoom in which I did not know before. From installing, learning to using the features makes me feels good. I try to operate gadget and find another helpful platform for learning."

Fifth, most students are not familiar with learning platform. They tend to use smartphone for gaming or chatting. Through the learning English via Zoom they learn something new, at least they learn to operate the useful features in Zoom from the very beginning until they used to do it. This can lead them to the next step way of learning by finding new platforms to learn English. One of the helpful features is chat, as a students said, "One of features that help me the most is Chat. We can use chat when the internet connection is not support to talk or when we are muted." Chat feature is helpful since it can be used to ask or state something when the meeting is going on. Some students are not quite confident to ask in spoken way, so they use this feature. Moreover, sometimes teacher also mute the participants microphone when delivering material in order not to get the sound distraction. When this happens, students can use chat to say something to be noticed. For the students with poor internet connection this feature is also helpful since they are hard to talk as the voice and display is delayed due to the connection as a student said, "I 
think remote control feature is so useful." Zoom provide remote control feature that allows participant to take control of another participant's screen in a meeting. The students can either request remote control of another participant's screen or the other participant can give control. Once given permission, students can control their mouse and keyboard, and even copy text from their screen. In English lesson, this feature is so helpful when teacher give questions, and students have to answer in written way especially the fill in the blank questions. The phone screen become the board where students can write something on screen as teacher give the access of remote control to someone chosen as a student claimed, "Pointer is so helpful to point the text or picture explained." The next useful feature is screen pointer. It is called co-annotate. It gives the access to every participant to use arrow, line, pen, etc. this feature, especially arrow, is useful to point the writing or picture explained.

Sixth, slow speed internet connection is still the biggest challenge for students in small cities. Poor internet connection and outdated hardware or limited phone memory as adequate digital device accessibility are still challenging in distance learning as the pandemic continues. This is said by students, "It is worse when the electricity is off because of the poor internet connection." "When the internet connection is poor, I miss the material because the display and sound is delay." When the internet connection is poor, the display and sound of meeting is delayed even stopped. This affects students' participation in learning process. This makes them left behind in understanding material. It is so much both disturbing and distracting students focus on learning. The phenomenon is one of big challenges in applying online learning in rural areas which the internet connection is not distributed well as a student said, "The main problem is the poor internet connection." Hopefully, Video conference through Zoom brings benefits as well as challenge for students. However, some students' condition does not quite support the expectation. Outdated smartphone is still the worst facts that students of junior high school in small cities must face. Some of them even share gadget with parents or other family member. Most students of junior high school are given the smartphone which is adequate for social media or browsing. Parents do not consider about buying the higher quality of smartphone since it indeed more expensive. However, the low priceof smartphone have low performance too. From the space of memory, RAM, battery power quality, features, etc. Some students stated that learning through Zoom make their phone lowbat. "Learning English thorugh Zoom consumes more battery power. 5 minutes meeting decrease 10\% battery power in my phone." It happens especially when the gadget is low level or the battery is old. So, they have to prepare well before meeting. Charging hp, making sure the internet data is adequate, stable internet connection etc. as a student said, "It's bad when the phone lags" For the low RAM gadget, big internet access such as Zoom sometimes does not work well. It can make the meeting suddenly stopped and handphone is hang which is then error.

Seventh, the problem of poor internet connection, sharing smartphone, outdated gadget, and even unstable environment decrease the benefits of Zoom use in learning. Due to this situation, a high expected feature to use, remote control, could not be operated well. Students with those problems were hard to use it. Moreover, Breakout Room even did not used at all because only a few students who have high speed internet connection. Another problem happened since Zoom meeting needs supporting environment. It means there have to be conducive. No distraction both sounds and people since it distracts the focus as students said, "The sounds of vehicles around my home is disturbing" In this case, headset is highly needed when the outdoor sounds is distracting. In addition, a student also said, "Sometimes my brothers are playing around" People are also distracting. They need focus and quiet place to join the meeting.

Last find, online learning of course related to parents' expense, especially for providing supporting gadget and internet quota. For them with low income, this is a big problem since free wifi access is not available in each area. "The internet connection is poor, it consumed a lot more data usage, and consumed great amount of battery power." Compared to other learning platform used previously such as Whatsapp, google form, google classroom etc., Zoom consume more data usage since it displays video conference and share screen. Some students feel they have to spend more money for internet quota because government did not give more quota in Januari-Februari 2021.

\section{Discussion}

In learning English, effective and direct communication is important since students can follow, imitate, have question and answer, and do exercise directly in every meeting. The findings of the study are in line with some previous study worked in the similar topic. Students assume that learning English through Zoom makes them easy to communicate with teachers, as most students agreed that they could communicate easily in an e-learning environment (Rahayu, 2020) since they have the real role model, teacher, who guide them in learning. It also sounds easier for students to understand the lesson than they have to follow one-way learning material individually. One-way communication or two-way indirect 
communications is something challenging in distance learning. In fact, Effective learning process happens when both teachers and students interact and actively participate in the learning activities (Abdullah, et al. 2015). This is because students will learn how to think critically and improve their intellectual development when they are active in the classroom (Mustapha, 2011). In addition, relatively high level of online learner-teacher interaction in both cases happens when anonline teacher presents content knowledge and also when the teacher asks studentsquestions (Li, 2016).

It opens opportunity for students to give feedback directly to lecturer face to face. The lecturer also can organize the online class via Zoom as he/she wants synchronizing with the course material he delivers. Having lesson via Zoom is almost similar with the real face-to-face learning activity in classroom. Communication flows naturally and teacher can organize the classroom based on the context of material. In language learning, students need more than instruction and command from their teachers as in the traditional class. This is a challenge for the teachers to be able to motivate their students to be focus and serious in class(Ulfa and Bania, 2019) sincesuccess in learning English will depend on motivation. In other words, learning and motivation are closely related to each other and profoundly affect one another (Jefiza, 2019). Similar with communication in traditional face-to-face, students were able to have informal chatting before the lesson starts such as to greet each other (Rahayu., 2020).Teacher is still being the main guide for them to do step by step learning. Therefore, the good communication is an appropriate effort to support students' understanding on English material and participation in learning. Students' active engagement in classroom is important in order to achieve effective learning and plays an important role in the success online teaching and learning quality (Gray \& Diloreto, 2016).

Online learning gives different perspective on students. For some of them it is fine to understand material without any help from teacher or friends, but the other students could not cope with the situation, especially they who study in small cities are not quite independent to learn and find resources by themselves. They need more clear explanation and interesting presentation especially the pictures or videos. In other words, learning English through video conference gives the chance for students to enlarge both their language learning experience and their speaking proficiency by engaging in real communicative tasks (Alshahrani, 2016). Moreover, the communication via chat is sometimes not quite effective since it may take long time to have discussion due to the slow response or even misunderstand about the explanation. Online Zoom tutorial sessions provided good interactive help (Shadat, et al., 2017). In periods of crisis, the ability to maintain communication is critical to allow accurate and up to date information to be disseminated (Wotherspoon, et al, 2020).

Another findings of the study revealed that online learning though Zoom video conference create more formal classroom as traditional learning since students have to be ready for joining lesson by showing that they sit properly, well dressed, and prepare learning tools. This is in line with. That Zoom can reduce feelings of social isolation and foster a sense of community among students (Yaman \& Muhlis 2020). By having video conference meeting, the classroom situation is more live. Students can see friends and teacher on screen and paying attention on teacher explanation. Video conference also providing autonomy and drawing upon students' topic interests may lead to greater levels of FL motivation, engagement and achievement, while still meeting the objective of the lesson (Hu \& McGeown, 2020). They also prepare the meeting well such as being ready on screen and formally join the class. It can also be used to determine and maintain emotional connection with students (Borup, West, And Graham 2012). That motivation affected directly to the students' willingness to communicate inEnglish. Thus, these results of studies indicated that learners' language acquisition has positively correlated with the degree of motivation they had (Fadilah, 2018).

Related to the features, Zoom considered advantageous in the teaching learning process. The various features that help online learning are the high value of Zoom(Monica \& Fitriawati, 2020). Screen pointer helps students focused on the screen pointed which relates to the material explained. Once the teacher joined the conference room, the spoken communication was controlled by the teacher such as to decide when to activate the speaker or to mute the students so that they could focus on the teacher. These features significantly helped the teacher to organize and control the communication process during the lesson (Rahayu, 2020). The ability to operate gadget and use technology for learning is essential for the time being. Technology was regarded as highly beneficial, both to improve students' general language abilities and to help students in learning the kind of English communication and language skills increasingly necessary for their academic and personal life (Parvin, 2015).

In the other side, students also gave opinion that the uses of Zoom are challenging. The students' perception is supported by the following previous studies. The features of Zoom may be difficult to access at first ( Dharma et al., 2017). Students also mentioned the bad internet bandwidth gives effect such as unclear voice in online platforms, bad delivered materials, lack of direct lecturer-students interaction, noisy and wasting a lot of internet quota. Moreover, some others rated it is not affordable in terms of 
internet data consumption, low economy class factor, and bad signal of internet. Some of their participants had to deal with slow internet network, system failure (computers or smartphones stopped working) and difficulty for locating other participants' posts. participants compainedthat they are constrained by unstable internet connection(Ramsook \& Thomas, 2019). Hence, slow internet connection and system failure obstructed them to perform speed/responsive writing as their chats were pending (Rinekso \& Muslim, 2020). The internet speed determines the smoothness of the learning process (Dharma et al., 2017). This also agrees with some other studies stated that students using Zoom experience difficulties such as unreliable internet connection, lack of quiet environment, and inadequate speakers or microphones (Alfadda \& Mahdi, 2021; Lowenthal \& West, 2020). Studies stated that claimed that students faced difficulty during the meeting via Zoom due to unreliable Internet connection or use of outdated machines or mobile devices, resulting in dropped calls, lost call connection, or lag (Archibald et al., 2019). Studies stated that said that the problem is further exacerbated by the fact that a large percentage of them have already had troubles with learning, and their possible absence from online-type education obviously worsens their chances Herman, 2020 in (Kristóf, 2020). It is an international experience that social disparities increase when distance education is introduced. For students who do not have access to education, this situation can open up a very serious and quite long-term set of problems. The chances of meeting the year-end requirements can be drastically reduced without the help of an instructor or even a parent. Unfulfilled tasks can have a long-term negative impact on students' school careers, and the chances of dropping out can be greatly increased. Permanent disadvantage can not only be caused by failure, the grades of better learners can also deteriorate, so further learning can be jeopardized. However, there are some technical constraints caused due to several issues like not enough skill to use the zoom platform and limited quota. The problem of ganget and signal mostly happen in junior high school students. There are also students who do not have a Smartphone or laptop (device) (Marlini, 2020). It can assume that students found it more complicated to download and upload files to the online platform compared to opening hardcopy books when they are in a traditional face-to-face classroom. It might also be assumed that because some of the participants chose to use their mobile phones or tablets instead of computers to join the online class, they could not have the access to the uploaded material files and could not submit their work through the chat features. These findings could be used as an input for the provider of synchronous learning to enhance the features, so that they could be accessed and operated by using broader types of gadgets (Novawan et al., 2020).

From the basic system, Zoom has its weakness especially for free access users. They can only last for 40 minutes. If it's been 40 minutes, the application will automatically exit and have to log in again with the new user id. In addition, students must have an extra network, so that there are no obstacles during learning (Monica \& Fitriawati, 2020). Seeing from the two-side perspectives, the benefits of the use of Zoom im ELT is that it can help students to practice English, make teaching-learning process more effective, and facilitate the lecturer-students interaction and communication. However, there are some disadvantages of the use of Zoom. The dominant problems to apply them are bad internet connection, low economy class and lack of supporting facility for internet bandwidth, for instance free wifi at campus and around.

\section{CONCLUSION}

In light of the research findings, it can be concluded that Zoom provides strength and challenges in distance English learning depends on the participants' personal motivation, teachers' creativity and preparation, and supportive gadgets, cost, and environment. From this research, it is suggested that government needs to take action to support the new education life by developing the facilities for people especially in small or rural city such as collaborate with internet provider to add signal tower or even giving free wifi access for students so that online learning with various platforms can be effective and run well. This study hopefully encourages other researcher to make researches on the same topic with different participants' education level, or they can study the similar topic in the junior high school students located in big cities in Indonesia to explore more strength and challenges of using Zoom for learning English.

\section{REFERENCES}

Abdullah, M. Y., Rahamah, N., Bakar, A., \& Mahbob, M. H. (2012). The Dynamics of Student Participation in Classroom: Observation on Level and forms of Participation The dynamics of student participation in classroom: observation on level and forms of participation. February 2015. 
https: //doi.org/10.1016/j.sbspro.2012.09.246.

Adila, J. (2019). Students' Motivation and Attitudes Toward Learning English in an English Course. Journal of Chemical Information and Modeling, 53(9), 1689-1699.

Alfadda, H. A., \& Mahdi, H. S. (2021). Measuring Students' Use of Zoom Application in Language Course Based on the Technology Acceptance Model (TAM). Journal of Psycholinguistic Research, 0123456789. https://doi.org/10.1007/s10936-020-09752-1.

Alshahrani, A. A. (n.d.). Communicating Authentically: E nhancing EFL Students 'Spoken English via Videoconferencing. 17(2), 1-17.

Archibald, M. M., Ambagtsheer, R. C., Casey, M. G., \& Lawless, M. (2019). Using Zoom Videoconferencing for Qualitative Data Collection : Perceptions and Experiences of Researchers and Participants. 18, 1-8. https://doi.org/10.1177/1609406919874596.

Borup, J., West, R. E., \& Graham, C. R. (2012). Improving online social presence through asynchronous video. Internet and Higher Education, 195-203. https://doi.org/10.1016/j.iheduc.2011.11.001.

Clandinin, D. J. (2006). Research Studies in Music Education. Society for Education, Music and Psychology Research Additional. https://doi.org/10.1177/1321103X060270010301.

Cuaca Dharma, H. R., Asmarani, D., \& Dewi, U. P. (2017). Basic Japanese Grammar and Conversation elearning through Skype and Zoom Online Application. Procedia Computer Science, 116, 267-273. https://doi.org/10.1016/j.procs.2017.10.055.

Dhawan, S. (2020). Online Learning: A Panacea in the Time of COVID-19 Crisis. Journal of Educational Technology Systems, 49(1), 5-22. https://doi.org/10.1177/0047239520934018.

Fadilah, E. (2018). Willingness To Communicate in L2 By Using. 5(1), 23-48.

Gray, J. A., \& Diloreto, M. (n.d.). The Effects of Student Engagement, Student Satisfaction, and Perceived Learning in Online Learning Environments. 11(1).

Hu, X., \& McGeown, S. (2020). Exploring the relationship between foreign language motivation and achievement among primary school students learning English in China. System, 89, 102199. https://doi.org/10.1016/j.system.2020.102199.

Kristóf, Z. (2020). International Trends of Remote Teaching Ordered in Light of the Coronavirus (COVID19) and its Most Popular Video Conferencing Applications that Implement Communication. Central European Journal of Educational Research, 2(2), 84-92. https://doi.org/10.37441/cejer/2020/2/2/7917.

Li, C. (Cecilia). (2016). A survey on Chinese students' online English language learning experience through synchronous web conferencing classrooms. CALL Communities and Culture - Short Papers from EUROCALL 2016, 2016(2016), 265-270. https://doi.org/10.14705/rpnet.2016.eurocall2016.573.

Lowenthal, P. R., \& West, R. E. (2020). Thinking Beyond Zoom: Using Asynchronous Video to Maintain Connection and Engagement During the COVID-19 Pandemic. 28, 383-391.

Miles, M. B., Huberman, A. M., \& Saldaña, J. (n.d.). Qualitative Data Analysis.

Mishra, L., Gupta, T., \& Shree, A. (2020). Online teaching-learning in higher education during lockdown period of COVID-19 pandemic. International Journal of Educational Research Open, June, 100012. https://doi.org/10.1016/j.ijedro.2020.100012.

Monica, J., \& Fitriawati, D. (2020). Efektivitas Penggunaan Aplikasi Zoom Sebagai Media Pembelajaran Online Pada Mahasiswa Saat Pandemi Covid-19. Jurnal Communio: Jurnal Jurusan Ilmu Komunikasi, 9(2), 1630-1640. https://doi.org/10.35508/jikom.v9i2.2416.

Mustapha, S. (2011). Classroom Participation Patterns: A Case Study of Malaysian Undergraduate Classroom Participation Patterns : A Case Study of Malaysian Undergraduate Students. January.

Novawan, A., Aisyiyah, S., Miqawati, A. H., Wijayanti, F., \& Indrastana, N. S. (2020). JER/ Journal of ELT Research. 5(1), 80-93. https://doi.org/10.22236/JER.

Oyedotun, T. D. (2020). Sudden change of pedagogy in education driven by COVID-19: Perspectives and evaluation from a developing country. Research in Globalization, 2(June), 100029. https://doi.org/10.1016/j.resglo.2020.100029.

Parvin, R. H. (2015). The Effectiveness of Using Technology in English Language Classrooms in Government Primary Schools in Bangladesh The Effectiveness of Using Technology in English Language Classrooms in. 2(1).

Patricia, A. (2020). College Students' Use and Acceptance of Emergency Online Learning Due to COVID-19. International Journal of Educational Research Open, 100011. https://doi.org/10.1016/j.ijedro.2020.100011.

Pokhrel, S., \& Chhetri, R. (2021). A Literature Review on Impact of COVID-19 Pandemic on Teaching and Learning. https://doi.org/10.1177/2347631120983481.

Purwanto, A., Pramono, R., Asbari, M., Santoso, P. B., Wijayanti, L. M., Choi, C. H., \& Putri, R. S. (2020). Studi 
Eksploratif Dampak Pandemi COVID-19 Terhadap Proses Pembelajaran Online di Sekolah Dasar. EduPsyCouns: Journal of Education, Psychology and Counseling, 2(1), 1-12.

Rahayu, D. (2020). Synchronous Zoom Web Conference System : An Exploratory Study on Students ' E Learning Experience. 5(1), 68-79. https://doi.org/10.22236/JER.

Ramsook, L., \& Thomas, M. (2019). Perspectives of Prospective Teachers on Zoom As a Transformative Teaching Methodology. International Journal for Innovation Education and Research, 7(11), 946957. https://doi.org/10.31686/ijier.vol7.iss11.1955.

Reimers, F. M., \& Andreas, S. (2020). A framework to guide an education response to the COVID - 19 pandemic of 2020. Oecd, 1-40.

Rinekso, A. B., \& Muslim, A. B. (2020). Synchronous online discussion: teaching English in higher education amidst the covid-19 pandemic. JEES (Journal of English Educators Society), 5(2), 155-162. https://doi.org/10.21070/jees.v5i2.646.

Sahu, P. (2020). Closure of Universities Due to Coronavirus Disease 2019 (COVID-19): Impact on Education and Mental Health of Students and Academic Staff. Cureus, 2019(4), 4-9. https://doi.org/10.7759/cureus.7541.

Shadat, A., Sayem, M., Taylor, B., \& Mcclanachan, M. (2017). Effective use of Zoom technology and instructional videos to improve engagement and success of distance students in Engineering. AAEE2017 CONFERENCE, 1-6.

Tinggi, S., Islam, A., \& Mandailing, N. (2021). Students 'Perceptions of the Use of Zoom and Whats App in ELT Amidst Covid19 Pandemic. 2(1), 51-64. https://doi.org/10.35961/salee.v2i01.212.

Ulfa, M., \& Bania, A. S. (2019). EFL student's motivation in learning English in Langsa, Aceh. Studies in English Language and Education, 6(1), 163-170. https://doi.org/10.24815/siele.v6i1.12860.

Wargadinata, W., Maimunah, I., Dewi, E., \& Rofiq, Z. (2020). Student's Responses on Learning in the Early COVID-19 Pandemic. Tadris: Jurnal Keguruan Dan Ilmu Tarbiyah, 5(1), 141-153. https://doi.org/10.24042/tadris.v5i1.6153.

Wotherspoon, R. J., Mannion, C. J., \& Harlow, R. E. A. (2020). Maintaining medical team communication using video conferencing during the COVID-19 lockdown. British Journal of Oral and Maxillofacial Surgery, 58(10), e326-e327. https://doi.org/10.1016/j.bjoms.2020.08.114.

Yaman, N., \& Muhlis, M. (2020). Students' Social Presence And Perceived Learning Toward Ccu Course In Online Classroom (An Evaluating of Learning Process during Pandemic Coronavirus). Elite English and Literature Journal, 7(1), 61. https://doi.org/10.24252/elite.v7i1a6. 